\title{
PERLINDUNGAN ISLAM TERHADAP BURUH
}

Setiawan bin Lahuri

Institut Studi Islam Darussalam (ISID) Gontor

binlahuri@gmail.com

\begin{abstract}
:
In Islam, the determination of wages is not only based on the quality of labor as the physical, mental, work experience, professionalism and so on. But there are other considerations, they are aspects of personal and family needs. Thus, there are important implications of the theory above, the Islamic theory of wage determination is in contrast to the capitalist economic system, and there are elements in common with the socialist economic system. Mechanisms of wage determination in Islam does not depend on the institutional market. Islam is a religion that upholds universal human values. Islam is very concerned with the rights and obligations of all people, including the workers and laborers. Teaching that can be seen from several hadith clearly provides real assurance that the workers have to work in a comfortable state, far from the threat of layoffs, delays in awarding salary, job demands beyond the limits of human ability and so on. Thus, Islam gives an overview of the importance of laborers and workers in human life. Islam gives us the importance of laborers and workers in human life. Islam thus providing strong values as a form of protection to the workers and employees.
\end{abstract}

Keywords: Determination, wages, workers

\section{Abstrak:}

Dalam Islam penentuan upah tidak hanya berdasarkan kepada kualitas buruh seperti aspek fisik, mental, pengalaman kerja, profesionalisme dan lain sebagainya. Akan tetapi ada pertimbangan lain yaitu aspek kebutuhan pribadi dan keluarga. Dengan demikian maka ada implikasi penting dari teori di atas yaitu Teori penentuan upah dalam Islam berbeda dengan sistem ekonomi kapitalis, dan ada unsur kesamaan dengan sistem ekonomi sosialis dan Mekanisme penentuan upah dalam Islam tidak bergantung kepada institusi pasar. Islam adalah agama yang menjunjung tinggi nilai-nilai universal manusia. Islam sangat memperhatikan hak dan kewajiban semua manusia, termasuk kaum pekerja dan buruh. Ajaran yang dapat dilihat dari beberapa hadis jelas memberikan jaminan nyata bahwa kaum pekerja harus bekerja dalam keadaan yang nyaman, jauh dari ancaman PHK, keterlambatan pemberian gaji, tuntutan pekerjaan di luar batas kemampuan manusia dan lain sebagainya. Dengan demikian, Islam memberikan gambaran kepada umat manusia betapa pentingnya 
buruh dan pekerja dalam kehidupan manusia. Sehingga Islam memberikan nilai-nilai yang kuat sebagai bentuk perindungan terhadap kaum buruh dan pekerja.

Kata Kunci: Penentuan, upah, pekerja

\section{Pendahuluan}

Fenomena buruh sedikit banyak telah menyedot perhatian umat manusia sejak terjadinya revolusi industri di Eropa pada abad XV yang memaksa manusia untuk bekerja di pabrik-pabrik, lahan tambang, perkebunan dan lain-lain. Revolusi industri yang diklaim sejarawan sebagai tonggak kebangkitan Eropa setelah sejak berabad-abad lamanya tenggelam dalam masa kegelapan, melahirkan fenomena-fenomena baru di tengah masyarakat. Di antaranya, muncul kelas pemodal (kaum borjuis) yang 'mengorganisasi' dan 'mengeksploitir' buruh untuk bekerja pada pabrik-pabrik mereka. Pada sisi lain, sistem feodalistik ini melahirkan kelompok masyarakat miskin, kelas pekerja (kaum proletar), yang menjadi 'budak' bagi para pemodal. Mereka diperas tenaganya secara paksa, tidak hanya orang lakilaki dewasa tapi juga anak-anak dan pekerja-pekerja wanita. Mereka diperlakukan dengan tidak manusiawi.

Ide liberalisme (kebebasan) dengan landasan utama sekularisme, yang menjadi acuan kebangkitan Eropa telah melahirkan keserakahan demi keserakahan dalam menggapai 'kemuliaan' dunia. Maka bangsa-bangsa Eropa ramai-ramai melancarkan imperialisme kepada bangsa-bangsa lain yang menguntungkan secara geografis termasuk adanya kekayaan alam. Tercatat seperti Inggris, Perancis, Belanda, Spanyol dan Portugis menjadi kolonialiskolonialis pada era itu hingga diusirnya mereka dari daerah jajahannya.

Jan Bremen seorang sosiolog Belanda, mengobservasi nasib para buruh pada masa kolonialisme Belanda (Jan Bremen, 1977). Lewat sebuah penelitian dengan memanfaatkan dokumen-dokumen resmi pemerintah kolonial yang selama ini tersembunyi, ia memaparkan praktik keji politik kolonial terhadap ribuan buruh atau kuli asal Cina, India, Jawa dan daerah-daerah lain di Sumatra yang dipekerjakan di perkebunan Sumatra Timur pada awal abad 19 hingga awal abad 20. Para kuli kontrak tersebut, tulis Jan Bremen -yang karena keberaniannya ia harus menanggung resiko dituduh tidak menghargai prestasi bangsanya sendiri- jika dianggap bersalah diperlakukan dengan sangat tidak manusiawi. Mereka disiksa layaknya binatang, dan masih banyak lagi kejadian-kejadian yang memilukan akibat imperialisme yang sudah menjadi bagian dari paradaban kapitalisme. 
Kapitalisme sebagai sebuah ideologi, memiliki aktivitas yang paling menonjol yakni mencari harta sebanyak-banyaknya dengan sebebas-bebasnya. Dengan demikian sampai saat ini pun aktivitas imperialisme dari ideologi kapitalisme belum berakhir. Bahkan semakin merajalela, dikarenakan ideologi kapitalisme menjadi ideologi tunggal setelah khilafah Islamiyah dihancurkan Barat pada tahun 1924 (Raziq, 1988), dan ideologi komunisme runtuh dengan sendirinya di tahun 1990 (ditandai dengan runtuhnya tembok Berlin).

Demi menyelesaikan problem perburuhan, para buruh di beberapa negara banyak yang membentuk partai politik . Partai politik ini mereka maksudkan untuk memperjuangkan kelas social (class strunggle) agar tercapai kesamaan diantara para buruh dan majikan. Teori ini dipengaruhi analisis Karl Marx yang bercita-cita menghilangkan sama sekali kelas dalam masyarakat ( masyarakat tanpa kelas ). Padahal dengan tergantinya pihak penindas (kaum borjuis) oleh kaum proletar (yang tertindas), maka orang yang tertindas itu kemudian ganti menjelma menjadi kelas penindas baru, sebagai tindakan konservatif (An-Nabhan, 2000).

Di Indonesia sendiri mulai nampak kesadaran kaum buruh akibat ulah kesewenangwenangan pengusaha yang tidak memberikan upah yang layak sebagai imbalan atas kerja mereka, PHK secara sepihak, dan lain-lain. Maka berbagai demonstrasi pun digelar (tidak jarang yang disertai pengrusakan) mogok kerja dan aksi-aksi lainnya dalam memperjuangkan nasibnya. Harga mahal yang harus dibayar akibat berbagai aksi tersebut, baik bagi buruh sendiri, pihak pengusaha dan stabilitas nasional pun terganggu. Buruh terancam PHK tanpa pesangon, buruh diintimidasi bahkan terancam jiwanya. Sementara pihak perusahaan menanggung reksiko kehilangan produktivitas, selain ancaman kerugian fisik akibat amuk buruh. Dan secara politis, persoalan ini menjadi lahan subur untuk menyusupkan ideologi komunisme, dengan senjata ampuhnya - pembelaan dan janji-janji indah kepada para buruh. Juga pemecahan dengan metode sekuler yang berakibat pada disfungsionalisasi ajaran agama. Bagaimanakah dengan Islam? Apakah aturan aturan Islam terhadap buruh dapat menyelesaikan dan menuntaskan problem perburuhan?

\section{Konsep buruh}

Buruh adalah sebuah upaya fisik dan mental yang dikeluarkan oleh manusia dalam proses produksi. Tenaga buruh adalah suatu komponen sumber daya manusia yang menjadi input dalam produksi barang dan jasa. Sebagai imbalan atas sumbangan itu, buruh diberi upah yang berbentuk uang atau barang atau yang lain. Bagi mayoritas penduduk terutama 
golongan miskin, upah adalah sumber utama pendapatan mereka, dan bagi negara pendapatan upah adalah komponen terbesar sumber pendapatan penduduk.

Penentuan kuantitas dan kualitas buruh serta kadar upah di sebuah negara, tidak saja dipengaruhi oleh sistem ekonomi yang dianut, tetapi juga oleh sistem nilai yang ada dalam masyarakat, serta pengalaman sejarah yang dilalui oleh negara tersebut. Kebanyakan negara kini cenderung untuk merespon dan bergantung kepada institusi pasar dalam mengatur kebutuhan terhadap buruh dan peraturan pemberian upah. Namun pada hakekatnya, sistem nilai atau norma yang berlaku di masyarakat dan pengalaman sejarah masing masing telah membedakan bentuk dan struktur pasar buruh di negara tersebut.

Dalam mencari formulasi konsep buruh dan upah, tidak harus selalu merujuk kepada ilmu ekonomi konvensional, karena teori yang mengkategorikan buruh sebagai input produksi bertentangan dengan konsep Islam bahwa manusia adalah khalifah Allah di bumi (Surtahman Kastin Hassan dan Abd. Ghafar Ismail, 2001). Jumlah buruh di suatu negara biasanya berbanding lurus dengan jumlah penduduk, apabila suatu negara memiliki penduduk yang padat, maka jumlah tenaga buruh pun melimpah.

Dalam istilah ilmu ekonomi, buruh dianggap sebagai sumber daya yang dimiliki manusia yang digunakan dalam proses produksi, sehingga buruh adalah input atau faktor pengeluaran atau biaya produksi. Sementara dalam Islam, faktor buruh tidak harus dianggap sebagai biaya produksi atau faktor pengeluaran, karena hal itu akan merendahkan derajat manusia sebagai wakil Allah di atas bumi. Seorang buruh yang menjual tenaganya untuk mendapatkan imbalan upah, sejatinya dia menjual sebagaian dari apa yang dimilikinya, dan bukan menjual dirinya. Maka tidak semestinya buruh dianggap sebagai faktor produksi atau biaya pengeluaran.

Menurut Abu Sulaiman buruh bukan faktor pengeluaran, karena buruh ada untuk memanfaatkan faktor pengeluaran (Abdul Hamid Abu Sulaiman, 1960). Dengan meletakkan buruh sebagai faktor pengeluaran maka manusia akan tunduk kepada manusia lain. Baqir al Sadr juga mempersoalkan buruh sebagai faktor pengeluaran, karena buruh adalah manusia dan bukan harta yang boleh dimiliki (as-Sadr, 1968).

Kenyataan bahwa buruh adalah manusia menimbulkan beberapa masalah dan kekeliruan apabila digunakan dalam analisis ekonomi. Pertama, tidak dapat membedakan 
antara manusia sebagai buruh dan bukan buruh. Dalam analisis ekonomi perbedaan ini seringkali amat penting, sebagai contoh dalam menganalisis sebuah perusahaan, perlu dibedakan antara perusahaan besar dan wiraswasta, antara pengusaha dan buruh yang pada hakekatnya adalah sama. Sebagai contoh lain apabila manusia dibedakan menurut jenis pendapatan, maka dibagi menjadi kelompok yang menerima pendapatan buruh dan pendapatan bukan buruh. Kedua, dengan menganggap buruh dan manusia adalah sama, maka isu hak milik terhadap buruh menjadi kabur. Sebagai contoh seorang penyalur tenaga kerja (buruh) yang menjual buruh kepada perusahaan, apakah ia juga menjual hak milik terhadap diri para buruh. Menganggap buruh adalah faktor pengeluaran berarti buruh tunduk kepada pemilik perusahaan yang artinya bahwa ada manusia yang tunduk kepada manusia lain. Dengan demikian umat Islam akan kembali kepada konsep perbudakan yang telah dihapuskan oleh Islam.

Sementara itu konsep buruh sebagai harta milik manusia tidak bertentangan dengan Islam. Hakekat bahwa manusia adalah khalifah di muka bumi (QS Al Baqarah: 30) memang wajib diakui, namun Islam juga menganjurkan manusia untuk bekerja guna mendapatkan upah (QS At-Thalaq: 6). Islam bahkan mengharuskan manusia untuk bekerja (QS At Taubah: 105, Al-An`am: 135, Hud: 93 \& 121, Az-Zumar: 39). Berdasarkan konsep inilah para ekonom muslim seperti Afzalur Rahman (1974), Muhammad Abdul Mannan (1970) dan Abu al-A`la al-Maududi (1969) tidak menafikan bahwa buruh sebagai faktor produksi (Euis Amalia, 2005).

\section{Kontrak kerja dalam Islam}

Di dalam Islam, problem perburuhan diatur oleh hukum-hukum kontrak kerja (ijarah). Secara definisi, ijarah adalah transaksi atas jasa/manfaat tertentu dengan suatu konpensasi atau upah (Al-Majlis al-A'la li asy-Syu'un al-Islamiyyah, 2001). Syarat tercapainya transaksi ijarah tersebut adalah kelayakan dari orang-orang yang melakukan aqad, yaitu penyewa tenaga atau majikan dengan orang yang dikontrak atau pemberi jasa/tenaga. Kelayakan tersebut meliputi: kerelaan (ridha) dua orang yang bertransaksi, berakal dan mumayyiz dan jelas upah dan manfaat yang akan di dapatnya.

Dengan pengertian di atas, maka kontrak kerja dalam Islam meliputi 3 jenis, yaitu: 1) Manfaat yang didapat seseorang dari benda, sebagai contoh seseorang menyewa rumah, kendaraan, komputer dan sejenisnya; 2) Manfaat yang didapat seseorang atas kerja /amal 
seseorang, semisal arsitek, tukang kebun, buruh pabrik dan sejenisnya; 3) Manfaat yang didapat seseorang atas pribadi atau diri orang lain, semisal mengontrak kerja atau menyewa seorang pembantu, satpam dan sejenisnya (Al-Majlis al-A'la li asy-Syu'un al-Islamiyyah, 2001).

Islam memperbolehkan seseorang untuk mengontrak tenaga para pekerja atau buruh, agar mereka bekerja untuk orang tersebut (QS Az Zukhruf: 32). Ibnu Syihab meriwayatkan dengan mengatakan, Aku diberitahu oleh Urwah bin Zubeir bahwa Aisyah r.a berkata: "Rasulullah SAW dan Abu Bakar pernah mengontrak (tenaga) orang dari Bani Dail sebagai penunjuk jalan, sedangkan orang tersebut beragama seperti agamanya orang kafir Quraisy. Beliau kemudian memberikan kedua kendaraan beliau kepada orang tersebut. Beliau lalu mengambil janji dari orang tersebut (agar berada) di gua Tsur setelah tiga malam, dengan membawa kedua kendaraan beliau pada waktu Subuh di hari yang ketiga".

Karena sewa menyewa atau kontrak kerja adalah memanfaatkan jasa sesuatu yang dikontrak dengan imbalan upah, maka seorang yang dikontrak haruslah dijelaskan bentuk kerjanya (job description), batas waktunya (timing), besar gaji/upahnya (take home pay) serta berapa besar tenaga/keterampilannya harus dikeluarkan (skill). Bila keempat hal pokok dalam kontrak kerja ini tidak dijelaskan sebelumnya, maka transaksinya menjadi rusak (fasid). Termasuk yang harus ditentukan adalah tenaga yang harus dicurahkan oleh pekerja, sehingga para pekerja tersebut tidak dibebani dengan pekerjaan yang di luar kapasitasnya. Maka tidak diperbolehkan untuk menuntut seorang pekerja agar mencurahkan tenaga, kecuali sesuai dengan kapasitasnya yang wajar.

Karena tenaga tidak mungkin dibatasi dengan takaran yang baku, maka membatasi jam kerja dalam sehari adalah takaran yang lebih ideal. Sehingga pembatasan jam kerja bisa mencangkup pembatasan tenaga yang harus dikeluarkan. Misalnya buruh harian, mingguan atau bulanan. Di samping itu bentuk pekerjaannya juga harus ditentukan, semisal menggali tanah, mengemudikan mobil atau bekerja di penambangan dan lain sebagainya.

Tiap pekerjaan yang halal, maka hukum kontrak kerja bagi pekerjaan tersebut juga halal. Sehingga kontrak kerja tersebut boleh dilakukan dalam perdagangan, pertanian, industri, pelayanan (jasa), perwakilan dan lain sebagainya. Apabila transaksi kerja tersebut dilakukan terhadap pekerjaan tertentu, atau terhadap pekerja tertentu, maka hukumnya wajib bagi pekerja tersebut untuk melakukan pekerjaannya sendiri. Dan secara mutlak posisinya 
tidak boleh digantikan oleh orang lain, karena dia telah diangkat dengan sebuah kesepakatan bersama. Sedangkan apabila kontrak kerja tersebut terjadi pada benda yang dideskripsikan dalam suatu perjanjian, atau terjadi pada pekerjaan yang telah dideskripsikan untuk melakukan kerja tertentu, maka dalam keadaan seperti ini si pekerja boleh saja mengerjakan pekerjaan itu sendiri atau boleh juga orang lain menggantikan posisinya, apabila dia sakit atau tidak mampu, selama pekerjaannya sesuai dengan deskripsinya.

Transaksi kontrak kerja dalam Islam, sangat memperhatikan sekali masalah waktu. Ini dikarenakan ada akad kerja yang menggunakan waktu dan ada pula yang tidak. Apabila pekerjaan yang memang harus disebutkan waktunya -tetapi tidak terpenuhi- maka pekerjaan tersebut menjadi tidak jelas dan tentu saja hukumnya menjadi tidak sah. Apabila waktu kontrak sudah ditentukan misalnya dalam jangka waktu 1 tahun atau 1 bulan, maka tidak boleh salah seorang diantara kedua belah pihak membubarkannya, kecuali apabila waktunya telah habis. Begitu pula tidak boleh seseorang bekerja untuk selamanya (tanpa waktu yang jelas) dengan perkiraan gaji yang juga tidak jelas.

\section{Buruh dan Upah}

Struktur hak milik terhadap buruh dan bentuk institusi yang mengatur penggunaan buruh dan penentuan upah adalah diantara faktor yang membedakan sistem ekonomi. Dalam Islam penentuan upah tidak hanya berdasarkan kepada kualitas buruh seperti aspek fisik, mental, pengalaman kerja, profesionalisme dan lain sebagainya. Akan tetapi ada pertimbangan lain yaitu aspek kebutuhan pribadi dan keluarga. Dengan demikian maka ada implikasi penting dari teori di atas yaitu (Hassan dan Ismail, 2001): 1) Teori penentuan upah dalam Islam berbeda dengan sistem ekonomi kapitalis, dan ada unsur kesamaan dengan sistem ekonomi sosialis; 2) Mekanisme penentuan upah dalam Islam tidak bergantung kepada institusi pasar.

Menurut Afzal ar-Rahman (1974) penawaran terhadap buruh ditentukan oleh 3 faktor yaitu: keahlian buruh, mobilitas dan jumlah penduduk. Profesionalisme buruh mengacu kepada kesehatan fisik dan mental, tingkat pendidikan, pelatihan atau pengalaman kerja yang membantu kecakapan bekerja. Dalam ilmu ekonomi konvensional profesionalisme buruh 
adalah faktor yang mempengaruhi tingkat produktivitasnya, dengan demikian maka penawaran terhadap buruh tergantung kepada produktivitasnya (Hassan dan Ismail, 2001).

Hal yang perlu dicatat bahwa meskipun faktor profesionalisme buruh mempengaruhi tingkat produktivitasnya, akan tetapi tidak selalu berakibat kepada meningkatnya kuantitas buruh yang ditawarkan. Karena penawaran terhadap buruh bergantung kepada masa kerja yang sanggup dikerjakan pada suatu tingkat upah tertentu. Maka pertanyaannya adalah apakah buruh yang tingkat pendidikannya tinggi akan bersedia menawarkan masa kerja yang lebih banyak pada tingkat upah tertentu. Yang terjadi adalah sebaliknya, semakin tinggi tingkat profesionalisme maka akan semakin keberatan menerima pekerjaan dengan upah yang rendah, dan ini menandakan penawaran terhadap buruh semakin berkurang.

Dalam ilmu ekonomi konvensional produktivitas buruh mempengaruhi permintaan terhadapnya. Semakin tinggi tingkat profesionalisme yang diberikan kepada proses produksi, maka akan semakin tinggi permintaan terhadap buruh, dan begitu juga sebaliknya. Akan tetapi dalam Islam, skema penentuan upah tidak tergantung pada permintaan terhadap buruh, atau paling tidak dianggap tidak relevan dalam penentuan upah. Maka pertanyaan yang muncul adalah apakah permintaan terhadap buruh tidak bergantung kepada upah, atau dengan kata lain apakah Islam menghendaki para pekerja mengabaikan faktor upah ketika membuat keputusan untuk menerima suatu pekerjaan?

\section{Penentuan upah}

Konpensasi yang berupa honor boleh dibayarkan tunai, boleh juga tidak. Honor tersebut juga bisa dalam bentuk harta (uang) atau pun jasa. Sebab apa saja yang bisa dinilai dengan harga, maka boleh juga dijadikan sebagai konpensasi, baik berupa materi maupun jasa, dengan syarat harus jelas. Apabila tidak jelas, maka transaksi tersebut tidak sah. Dengan kata lain, gaji (upah) haruslah jelas sejelas-jelasnya, sehingga bisa menafikan kekaburan, dan bisa dipenuhi tanpa ada permusuhan.

Penentuan upah/gaji dalam Islam adalah berdasarkan jasa kerja atau kegunaan /manfaat tenaga seseorang. Berbeda dengan pandangan kapitalis dalam menentukan upah, mereka memberikan upah kepada seorang pekerja dengan menyesuaikannya dengan biaya hidup dalam batas minimum. Mereka akan menambah upah tersebut, apabila beban hidupnya bertambah pada batas yang paling minimum. Sebaliknya mereka akan menguranginya, 
apabila beban hidupnya berkurang. Oleh karena itu, upah seorang pekerja ditentukan berdasarkan beban hidupnya, tanpa memperhatikan jasa yang diberikan oleh tenaga seorang atau masyarakat.

Dalam kondisi apapun, selama perkiraan tersebut tetap mengacu pada sarana-sarana kehidupan paling minim yang dibutuhkan oleh seorang pekerja, maka itu akan mengakibatkan kepemilikan para pekerja tersebut tetap terbatas, sesuai dengan standar paling minimum yang mereka butuhkan untuk memenuhi kebutuhan-kebutuhan mereka, sebagaimana yang dialami oleh pekerja yang terdapat di negara-negara yang terbelakang pemikirannya, seperti negara negara Islam, ataupun cukup untuk memenuhi kebutuhankebutuhan primer serta sekunder dan tersier mereka, sebagaimana yang dialami pekerja di negara-negara yang sudah maju pemikirannya, seperti Eropa dan Amerika. Maka pekerja yang ada di sana -baik yang maju ataupun belum- tetap saja sama nasibnya. Kepemilikan para pekerja dibatasi sesuai dengan batas taraf hidup mereka yang paling minim, menurut ukuran komunitas mereka. Padahal tinggi rendahnya masyarakat berbeda antara satu dengan yang lainnya, namun perkiraan tersebut tetap mengikuti biaya hidup minimum yang dibutuhkan oleh pekerja tersebut. Inilah mekanisme penetapan upah dalam sistem ekonomi kapitalisme (An-Nabhan, 2000).

Pandangan kapitalis di atas jelas tidak menghargai sama sekali jasa seseorang dan juga profesionalitas pekerja. Hal ini pun bertentangan dengan tingkat kebutuhan manusia yang berbeda-beda yang ingin dipenuhi, akhirnya pekerja sendiri yang harus mampu menekan tingkat kebutuhan tersebut. Di dalam Islam jelas berbeda penanganannya, profesionalisme kerja sangat dihargai oleh Islam. Sehingga upah seorang pekerja benar-benar didasari pada keahlian dan nilai manfaat yang bisa diberikan oleh pekerja itu, bukan yang lainnya. Dalam mekanisme penetapan upah, Islam menjelaskan adanya dua prinsip dasar yaitu: 1) Upah harus sebanding dengan kualitas kerja atau profesionalisme pekerja dan nilai manfaat yang dihasilkan; 2) Upah harus melebihi batas minimum kebutuhan pokok seseorang.

Di sini perlu dicatat bahwa mekanisme penetapan upah dalam Islam mempunyai kesamaan dengan dengan sistem sosialisme, dimana manfaat ekonomi dan kualitas pekerjaan adalah asas dalam penetapan upah (K. S., 1996). Penetapan upah sesuai dengan kualitas kerja adalah berdasarkan kepada prinsip bahwa manusia diciptakan dengan kemampuan dan keahlian yang berbeda beda (QS An-Nisa: 32, 6). Dalam kehidupan ekonomi global seperti 
dewasa ini, di samping dua prinsip dasar di atas, perlu ditambahkan prinsip musyawarah atau negoisasi (tawar menawar) antara pemilik perusahaan dan pekerja. Dengan kata lain pasar buruh adalah mekanisme yang menjelaskan proses tawar menawar antara pemilik perusahaan dengan pekerja dalam menentukan upah dan syarat syarat kerja antara kedua belah pihak.

Penetapan upah berdasarkan prinsip harus melebihi batas minimum kebutuhan pokok seseorang didasarkan pada QS An-Nisa : 6. Meskipun sekarang telah ditetapkan batas upah minimum terhadap buruh, akan tetapi pada kenyataannya di beberapa negara, upah yang diterima buruh tetap saja jauh dari standar untuk mampu hidup layak sesuai dengan kebutuhan pokok mereka.

\section{Perlindungan terhadap buruh}

Selain memberikan aturan yang jelas dalam hal transaksi kontrak kerja, Islam pun telah memberikan hukum hukum yang harus diperhatikan bagi para pemilik perusahaan untuk memberikan perlindungan kepada pekerja. Hal-hal tersebut menyangkut: 1) Perlindungan terhadap pekerja dan waktu istirahat yang layak (H. R. Al-Baihaqy); 2) Jaminan penghidupan bagi pekerja (H. R. Al Nasai); 3) Menyegerakan membayar gaji (upah) (H. R. Abu Dawud).

Di samping ketiga hal di atas, hendaknya gaji dibayarkan secepat mungkin dan sesuai dengan kesepakatan yang telah dicapai, begitu pula para majikan dilarang memotong gaji buruh dengan alasan apapun.

Pertanyaan selanjutnya adalah siapa yang menanggung kesejahteraan para buruh? Hal ini sering menjadi sumber problema perburuhan. Saat ini terdapat kecenderungan pemahaman bahwa kesejahteraan pekerja adalah tanggung jawab pengusaha, yaitu dengan mencukupi KHM (kebutuhan hidup minimum) seorang pekerja - yang biasanya mencangkup kontrak rumah, kebutuhan akan makanan pokok sampai rekreasi. Negara dalam hal ini seolah-olah lepas tangan sama sekali dari kewajiban di atas. Keadaan seperti ini sudah tentu tidak sesuai dengan nilai dan ajaran Islam, menurut Islam negara harus mengatur dan mengurus kepentingan rakyanya (H. R. Ahmad dan Abu Dawud).

Di samping hal hal yang mencakup kebutuhan hidup minimum, sektor kesehatan dan pendidikan adalah kebutuhan dasar masyarakat yang harus dipenuhi oleh negara. Sebab 
kedua sektor tersebut termasuk dalam katagori pemeliharaan kemaslahatan umum. Negara harus menjamin seluruh fasilitas kesehatan dan pendidikan yang memadai sehingga dapat dinikmati oleh seluruh warga negara, tidak terkecuali para buruh. Dengan demikian tidak akan terjadi lagi tarik ulur antara pengusaha dengan buruhnya mengenai masalah ini.

\section{Praktik Neo Liberalisme di lapangan industri}

Di lapangan industri, neo liberalisme dijalankan melalui skema hubungan industri yang disebut sistem Labour Market Flexibility (LMF) atau sistem pasar tenaga kerja yang fleksibel. Sistem LMF ini dimaksudkan untuk mempermudah dan memberikan keleluasaan kepada para pengusaha untuk mengakumulasi keuntungan setinggi-tingginya. Dengan sistem ini, pengusaha bebas mengembangkan modalnya tanpa harus dibebani dengan biaya produksi yang yang tinggi dan tanggungjawabsosial terhadap tenaga kerja (buruh).

Sistem LMF ini memungkinkan pengurangan sebanyak mungkin jumlah pekerja tetap di dalam suatu perusahaan, dengan dijalankannya skema outsourcing atau sistem kerja kontrak. Bagi pengusaha, dengan pengurangan jumlah tenaga kerja tetap, secara otomatis akan turut meminimalisasi biaya produksi agar keuntungan yang lebih maksimal bisa dikeruk. Pihak pengusaha tidak perlu lagi membayar bonus, jaminan sosial tenaga kerja, dana pensiun atau biaya pesangon kepada buruh, ketika terjadi Pemutusan Hubungan Kerja (PHK).

Pada saat bersamaan, penerapan sistem pasar tenaga kerja yang fleksibel ini akan memperlemah kekuatan posisi tawar dan perlindungan terhadap hak-hak buruh. Melalui skema outsourcing dan sistem kerja kontrak ini, setiap saat pihak pengusaha dengan mudah mengganti buruh yang dianggap mengancam atau mengganggu keberlangsungan usahanya.

Apalagi supply tenaga kerja begitu mudah diperoleh melalui perusahaan-perusahaan penyedia jasa tenaga kerja yang saat ini sudah menjamur di mana-mana. Penerapan sistem LMF ini didesain agar (di pasar tenaga kerja tentunya), tercipta persaingan yang tajam antar buruh atau pencari kerja, sehingga di sisi lain akan memperkuat posisi tawar pihak pengusaha dalam menentukan nominal besarnya upah buruh.

Lebih dari itu, upaya pengurangan jumlah tenaga kerja tetap dan pengembangan skema kerja outsourcing atau sistem kerja kontrak, sesungguhnya juga dimaksudkan untuk mengurangi (atau bahkan menutup) kemungkinan bagi kaum buruh, untuk memperjuangkan hak-haknya melalui organisasi atau serikat-serikat buruh yang sifatnya permanen, karena mayoritas dari mereka memang bukanlah buruh tetap. 


\section{Membangun solidaritas buruh}

Dengan uraian di atas, dapat dibayangkan bagaimana dampak yang ditimbulkan oleh praktik neo liberalisme di lapangan industri melalui penerapan Labour Market Flexibility (LMF). Namun demikian, situasi yang dirancang dan diterapkan secara sistematik di lapangan industri ini, bukan tidak disadari kaum buruh Indonesia. Dalam kenyataannya, sistem pasar tenaga kerja yang fleksibel ini di sisi lain, justru telah berhasil mendidik kesadaran kelas di kalangan kaum buruh. Mulai dari persoalan kepentingan siapa yang diuntungkan, bagaimana sistem itu bekerja, dan yang lebih penting lagi, bagaimana dan dengan cara apa sistem ini harus dihadapi.

Kaum buruh Indonesia hari ini, adalah kelas pekerja yang terdidik kesadarannya dari kerja-kerja dinamis berproduksi di kawasan-kawasan industri dengan upah yang rendah dan tidak dilindungi hak-haknya secara layak, baik oleh pengusaha maupun pemerintah. Di tangan mereka, sistem pasar tenaga kerja yang fleksibel (LMF), yang semula dimaksudkan oleh pemilik modal untuk mematahkan kekuatan kolektif kaum buruh, justru dijadikan alat untuk membangun organisasi atau serikat-serikat di berbagai tingkatan: dari pabrik-pabrik, di kawasan-kawasan industri, di tingkat Kabupaten/Kota, Provinsi, Nasional sampai ke level internasional.

Semakin fleksibel sistem ketenagakerjaan yang dijalankan, semakin mendorong perkembangan organisasi-organisasi buruh, secara kuantitatif maupun kualitatif. Kalau diamati secara seksama, perkembangan gerakan buruh di Indonesia pasca tumbangnya rejim Orba, sesungguhnya sedang tumbuh dalam situasi yang tidak pernah terduga sebelumnya di bawah penerapan sistem pasar tenaga kerja yang fleksibel. Sebaran jangkauan kerja organisasi-organisasi buruh di Indonesia saat ini, dibangun secara sungguh-sungguh dari waktu ke waktu, hingga menjangkau hampir seluruh wilayah, terutama di tingkatan provinsi. Sekedar menyebut contoh, hanya dalam jangka waktu beberapa tahun proses konsolidasinya, Kongres Aliansi Serikat Buruh Indonesia (KASBI), salah satu organisasi gerakan buruh tingkat nasional yang didirikan di awal tahun 2005, kini telah memiliki struktur organisasi di 13 Provinsi dan 19 Kota, dengan jumlah anggota tidak kurang dari 100 ribu orang.

Melihat perkembangan dinamis aksi-aksi kolektif dan kerja-kerja konsolidasi yang mereka jalankan selama beberapa tahun terakhir, memberikan satu harapan besar akan tumbuhnya kesadaran kelas di kalangan kaum buruh Indonesia . Gerakan yang di bangun 
kaum buruh Indonesia saat ini, sesungguhnya telah berkembang menjadi satu gerakan rakyat yang lebih sistematis dan terorganisasi secara baik, didasarkan atas analisis sosial yang tepat, memiliki cita-cita dan tujuan, sampai pada kejelasan rumusan strategi taktik dan program perjuangan yang akan dijalankan.

Dengan demikian, penerapan Labour Market Flexibility (LMF), yang pada dasarnya merupakan wujud nyata dari dominasi sistem ekonomi neo-liberal di Indonesia, telah mendidik dan menuntun kaum buruh Indonesia untuk sampai pada satu kesimpulan, bahwa menghadapi kekuatan neoliberalisme sebagai satu sistem ekonomi global, persatuan kaum buruh di Indonesia dan seluruh dunia merupakan sebuah heharusan.

\section{Penutup}

Ibnu Kholdun menyatakan bahwa manusia adalah makhluk yang hidup dengan berkelompok, tidak ada satupun manusia yang mampu hidup dengan dirinya sendiri (Ibnu Kholdun, Al Muqaddimah). Dengan demikian, Islam telah meletakkan dasar-dasar hubungan antara perusaaan dengan pekerja. Pekerja dan pemilik modal berada dalam level 'kemanusiaan' yang sama dalam Islam. Tidak ada yang berada di tempat lebih tinggi, meskipun dalam struktur perusahaan jelas ada kelompok pemilik modal, pemilik saham, pekerja dan lain sebagainya.

Dalam beberapa hadis dijelaskan bahwa pekerja demi meningkatkan produktifitasnya, para pemilik modal harus memenuhi hak-hak mereka. Di antaranya hak untuk bekerja sesuai dengan kemampuannya, hak untuk mendapatkan gaji sesuai dengan taraf hidup di masyarakat dan hak untuk melaksanakan kewajiban-kewajiban agamanya, selama berada pada jam kerja. Seringkali aspek ini dilupkan oleh pihak pemilik modal dengan dalih mengejar tingkat produktivitas, tingkat kualitas dan tingkat privasi tertentu.

Masalah waktu penyerahan gaji merupakan masalah yang sangat krusial dalam pola hubungan antara pekerja dengan pemilik modal. Dalam beberapa kasus ditemukan bahwa di antara factor-faktor yang menyebabkan demontrasi buruh, sikap mogok dan lain sebagainya adalah keterlambatan perusahaan dalam membayarkan gaji pekerja. Islam dengan tegas menyatakan bahwa hak atau gaji pekerja dan buruh, harus diberikan tepat waktu, harus diberikan sesuai dengan waktu yang telah disepakati. Bahkan dalam Hadis disebutkan bahwa pemberian gaji kepada buruh sebaiknya diberikan langsung setelah selesai pekerjaan. Tentu 
di sini bisa diartikan bahwa segera di sini artinya adalah sesuai dengan waktu yang telah disepakati bersama.

Islam adalah agama yang menjunjung tinggi nilai-nilai universal manusia. Islam sangat memperhatikan hak dan kewajiban semua manusia, termasuk kaum pekerja dan buruh. Ajaran yang dapat dilihat dari beberapa hadis jelas memberikan jaminan nyata bahwa kaum pekerja harus bekerja dalam keadaan yang nyaman, jauh dari ancaman PHK, keterlambatan pemberian gaji, tuntutan pekerjaan di luar batas kemampuan manusia dan lain sebagainya. Dengan demikian, Islam telah memberikan gambaran betapa pentingnya buruh dan pekerja dalam kehidupan manusia. Sehingga Islam memberikan nilai-nilai yang kuat sebagai bentuk perindungan terhadap kaum buruh dan pekerja.

\section{Daftar Pustaka :}

Al-Majlis al-A`la li asy-Syu’un al-Islamiyah. 2001. Al-Mausu`ah al-Islamiyah al-`Amah, Wazarat al Awqaf. Kairo.

Amalia, Euis. 2005. Sejarah Pemikiran Ekonomi Islam dari Masa Klasik Hingga Kontemporer. Pusaka Asatrus. Jakarta.

An-Nabhan, Muhammad Faruq. 2000. Sistem Ekonomi Islam: Pilihan Setelah Kegagalan Sistem Kapitalis dan Sosialis. alih bahasa Muhadi Zainuddin. UII Press. Yogyakarta.

As-Sadr, Muhammad Baqir. 1968. Iqtishaduna. Dar al Fikr. Beirut.

Chapra, M. Umer. 2000. Islam dan Tantangan Ekonomi, Gema Insani, Jakarta. 2001. Masa Depan Ilmu Ekonomi: Sebuah Tinjauan Islam. Gema Insani. Jakarta. 
Haneef, Mohamed Aslam. 2006. Pemikiran Ekonomi Islam Kontemporer: Analisis Komparatif Terpilih. Airlangga University Press. Surabaya.

Hariandja, Marihot Tua Efendi. 2002. Manajemen Sumber Daya Manusia. Grasindo. Jakarta.

Hassan, Surtahman Kastin dan Abd. Ghafar Ismail. 2001. Tenaga buruh dan upah dalam Islam, Jurnal Islamiyyat, No. 22.

Karim, Adiwarman Azwar. 2006. Sejarah Pemikiran Ekonomi Islam. Raja Grafindo Persaja. Jakarta.

K.S, Jomo. 1996. Alternatif Ekonomi Islam: Perspektif Kritis dan Haluan Baru. Dewan Bahasa dan Pustaka. Kuala Lumpur.

Mursi, Abdul Hamid. 1997. SDM yang Produktif: Pendekatan Al-Quran \& Sains. Gema Insani Press. Jakarta.

Raziq, Ali Abdur. 1988. Al Islam wa Ushul al Hukmi. Al Muassasah al `Arabiyah lid Dirasat wa an Nsyr, Lebanon.

Sulaiman, Abdul Hamid Ahmad Abu. 1960. Economic Theory of Islam: The Philosophy and Contemporary Means. Dar Misr lit Tiba`ah. Kairo.

Tasmara, Toto. 1995. Etos Kerja Pribadi Muslim. Dana Bhakti Wakaf. Yogyakarta. 